\title{
Removal of non-specific serum inhibitors of haemagglutination of rubella virus by treatment with dodecylamine-gel
}

\author{
W. K. K. HO AND K. F. SHORTRIDGE
}

From the Department of Biochemistry, The Chinese University of Hong Kong, Shatin, New Territories and the Department of Microbiology, University of Hong Kong, Queen Mary Hospital Compound, Hong Kong

SYNOPSIS The suitability of using dodecylamine-gel for removing the serum non-antibody-like inhibitors of haemagglutination by rubella virus was studied. Compared with kaolin and $\mathrm{MnCl}_{2} /$ heparin treatment this new procedure appears to have a higher specificity since it removes the non-antibody-like inhibitors from serum without affecting the immunoglobulin level significantly. The potential application of this procedure in routine serological analysis for rubella virus infection is discussed.

The haemagglutination inhibition test has great merits in aiding the diagnosis of a number of diseases connected with virus infection. The method is basically simple and economical and could be carried out in any clinical laboratory with a minimal amount of specialized equipment. In the laboratory diagnosis of rubella infection, a critical setback of this procedure is due to the presence of non-antibodylike inhibitors of haemagglutination in serum. If these non-antibody-like inhibitors are not removed before the titration of the antibody, a fortuitous higher inhibitory titre might result. In the case of rubella virus, these non-antibody-like inhibitors have been identified as the serum low and very low density lipoproteins (Feldman, 1968; Laufs and Thomssen, 1968; Haukenes and Aasen, 1971; Chang and Weinstein, 1972; Shortridge and Ho, 1974). There are currently two widely used procedures to remove these inhibitors from serum. They are treatment with either kaolin or $\mathbf{M n C l}_{2} /$ heparin (Mann et al, 1967) to adsorb or precipitate the lipoproteins from the samples to be tested. Both of these procedures appear to be quite effective in the removal of the serum lipoproteins; however, kaolin suffers from the drawback that it removes part of the serum immunoglobulins also (Mann et al, 1967; Monath et al, 1970; Schmidt et al, 1971). As a result, a falsely lower inhibitory titre may be obtained.

Recently, Deutsch et al (1973) reported a technique for removing lipids from serum by affinity chromatography on agarose beads with covalently attached

Received for publication 16 March 1976 dodecylamine arms. In the light of their success we explored the potential application of this procedure to remove the non-antibody-like inhibitors from serum.

\section{Material}

All chemicals used were reagent grade. Dodecylamine was obtained from Koch Light Laboratories Ltd, Colnbrook, Buckinghamshire, UK. Agarose beads (Sepharose 4B), cyanogen bromide, and 2,4,6trinitrobenzenesulfonic acid were from Pharmacia Fine Chemical AB (Uppsala, Sweden), Eastman Kodak (Rochester, New York, USA), and Sigma Chemical Co (St. Louis, Mo, USA), respectively. Frozen serum samples from confirmed cases of rubella infection were kindly supplied by $\mathrm{Dr} P$. Huggin, Virus Reference Laboratory, Central Public Health Laboratory, Colindale, London.

\section{Methods}

Dodecylamine-gel was prepared exactly as described by Deutsch et al (1973). The attachment of dodecylamine onto the Sepharose 4B beads was qualitatively demonstrated by reacting the beads with 2,4,6-tri-nitrobenzenesulfonate to produce a stable orange colour (Cuatrecasas and Anfinsen, 1971). The dodecylamine-gel was stored in $0.01 \mathrm{M}$ tris $\mathrm{HCl}, \mathrm{pH}$ $7 \cdot 4$, containing $0.19 \mathrm{M} \mathrm{NaCl}$ and $0.1 \mathrm{mg} / \mathrm{ml}$ EDTA at $4^{\circ} \mathrm{C}$ until use.

The non-antibody-like inhibitors of haemagglutination were removed from serum by either kaolin, 
$\mathrm{MnCl}_{2} /$ heparin or dodecylamine-gel treatment. The first two procedures were carried out essentially as described by Mann et al (1967). As for the dodecylamine-gel treatment, $1 \mathrm{ml}$ of the test serum was first mixed with $0.5 \mathrm{~g}$ packed wet gel and the mixture was rotated gently at room temperature for $20 \mathrm{~min}$. At the end of this period, the gel particles were pelleted by centrifuging at $2000 \mathrm{rev} / \mathrm{min}$ for 10 min. The clear supernatant obtained was analysed for its inhibitory activity as well as its chemical composition. For the control, serum was treated similarly except that Sepharose 4B beads were substituted for dodecylamine-gel.

The test for inhibition of haemagglutination by rubella virus was carried out in microplates using gander erythrocytes, as described earlier (Shortridge and Ho, 1974). The rubella virus antigen (Baylor strain) used was obtained from Grand Island Biological Co, Oakland, Calif, USA. Titrations were performed in duplicate and in each case yielded identical results.

Protein and total lipid determinations were performed as described before (Shortridge and Ho, 1974). Double immunodiffusion assay was done by the method of Hatch and Lees (1968) in $1 \%$ agarose plates. Antiserum raised in guinea-pigs for the low and very low density lipoproteins was kindly provided by Dr P. Y. Chau, Department of Microbiology, University of Hong Kong. Goat antiserum for the human immunoglobulins was purchased from Hyland Laboratories, Costa Mesa, Calif, USA. The concentrations of $\operatorname{IgA}, \operatorname{IgE}$, and $\operatorname{IgG}$ were measured by the radial immunodiffusion technique of Man- $\frac{D^{*}}{5}$ cini et al (1965) using immunoplates containing 으.specific antisera and antigen reference standards $\overrightarrow{\vec{F}}$ (Oxford Laboratories, Foster City, Calif, USA).

\section{Results}

In orienting experiments we first assess the effective- $\stackrel{\mathbb{Q}}{\Omega}$ ness of the dodecylamine-gel in removing the lipid components from two normal human serum $\vec{\circ}$ samples. As indicated in table $I$, a significant portion of the serum lipids was removed after $\vec{\omega}$ treatment with a concomitant decrease of inhibitory

\begin{tabular}{|c|c|c|c|}
\hline \multirow[t]{2}{*}{ Serum } & \multicolumn{3}{|c|}{$\%$ reduction after treatment } \\
\hline & Total protein & Total lipid & Inhibitory activity \\
\hline $\begin{array}{l}\text { WH' } \\
\text { MD }\end{array}$ & $\begin{array}{l}19 \\
34\end{array}$ & $\begin{array}{l}70 \\
91\end{array}$ & $\begin{array}{l}83 \\
89\end{array}$ \\
\hline
\end{tabular}

Table I Effect of dodecylamine-gel treatment in removing lipid, protein, and haemagglutination inhibitory activity from normal sera

${ }^{1}$ This serum sample was highly lipaemic $(>600 \mathrm{mg} / 100 \mathrm{ml})$, and it is likely that the binding sites on the dodecylamine-gel had been saturated.

activity when titrated against rubella antigens. $\operatorname{ma} \vec{\theta}$ addition to the lipids, dodecylamine-gel treatmein oे also removed a fair portion of the serum proteins. In order to assess whether this had affected the serum immunoglobulin level, double gel immunodiffusion was performed on the treated and untreated materials using antiserum prepared against the low

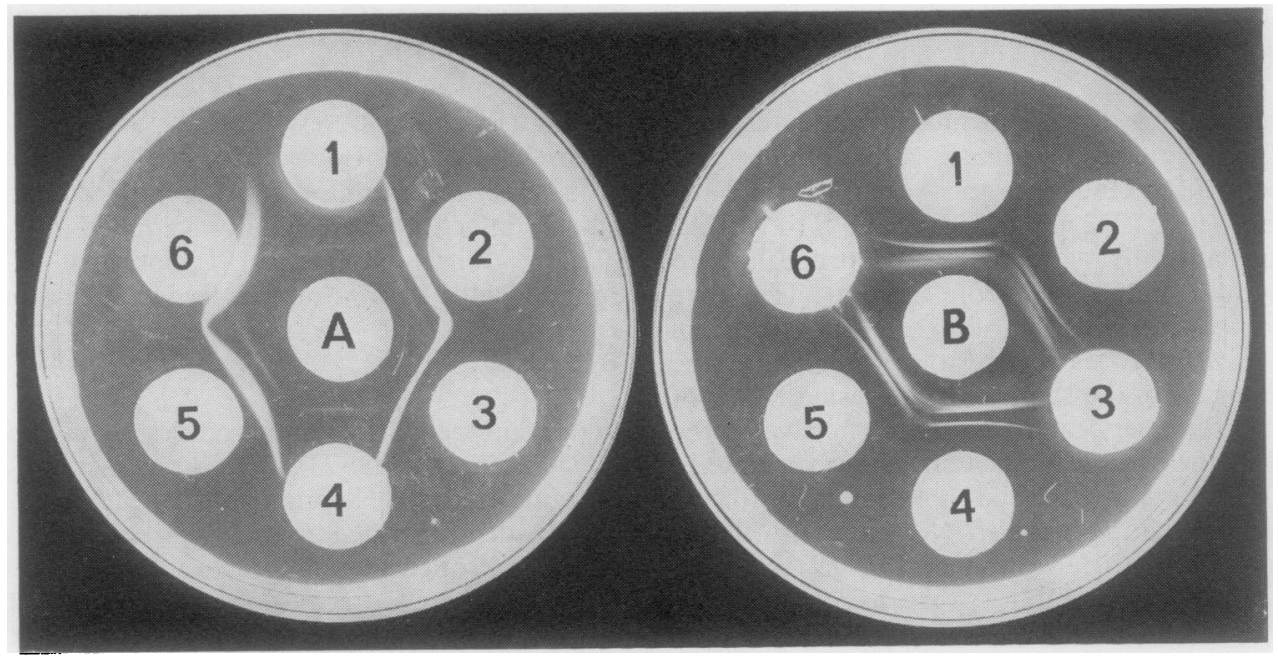

Figure Immunodiffusion pattern of sera treated with dodecylamine-gel. Samples in holes 1, 2, 3, 4, 5, and 6 correspond to $W H$ serum treated, $W H$ serum control, pure low density lipoprotein, $M D$ serum treated, $M D$ serum control, and pure very low density lipoprotein, respectively. Pattern A centre well contained antiserum for low and very low density lipoproteins. Pattern B centre well contained antiserum for the immunoglobulins. 
and the very low density lipoproteins and against the total immunoglobulin fraction. As shown in the figure, precipitin lines corresponding to the low and the very low density lipoproteins were essentially absent in the samples treated with the gel while those corresponding to the immunoglobulins were unchanged.

When the dodecylamine-gel procedure was compared with the two conventional procedures, viz, kaolin and $\mathrm{MnCl}_{2}$ /heparin treatment, in removing non-antibody-like inhibitors of haemagglutination in sera of confirmed cases of rubella virus infection, a general reduction of inhibitory activity, probably due to the removal of the non-antibodylike inhibitors, was observed in all three methods of treatment. The magnitude of reduction was highest for kaolin, intermediate for $\mathrm{MnCl}_{2} /$ heparin, and lowest for dodecylamine-gel (table II). The reason why kaolin treatment reduced the inhibitory activity more than the other two procedures may be due to the fact that kaolin can remove, in addition to the

\begin{tabular}{|c|c|c|c|c|c|c|}
\hline \multirow[t]{3}{*}{ Serum } & \multicolumn{6}{|c|}{ Inhibitory activity } \\
\hline & \multicolumn{2}{|l|}{ Kaolin } & \multicolumn{2}{|c|}{$\mathrm{MnCl}_{2} /$ heparin } & \multicolumn{2}{|c|}{ Dodecylamine-gel } \\
\hline & Control & Treated & Control & Treated & Control & Treated \\
\hline 73 & 160 & 10 & 256 & 64 & 256 & 128 \\
\hline 71 & 320 & 10 & 456 & 64 & 256 & 128 \\
\hline 55 & 960 & 10 & 1024 & 64 & 768 & 128 \\
\hline 44 & 160 & 10 & 256 & 64 & 256 & 192 \\
\hline 43 & 480 & 10 & 512 & 64 & 512 & 128 \\
\hline 22 & 320 & 30 & 512 & 192 & 512 & 96 \\
\hline 18 & 640 & 15 & 512 & 128 & 512 & 192 \\
\hline 81 & 480 & 60 & 384 & 128 & 384 & 128 \\
\hline 82 & 480 & 60 & 384 & 128 & 384 & 192 \\
\hline 83 & 160 & 15 & 128 & 96 & 128 & 128 \\
\hline 85 & 320 & 60 & 512 & 128 & 384 & 192 \\
\hline 91 & 960 & 60 & 512 & 192 & 512 & 192 \\
\hline 80 & 320 & 16 & 256 & 32 & 256 & 96 \\
\hline 77 & 1280 & 30 & 2048 & 96 & 2048 & 192 \\
\hline
\end{tabular}

Table II Comparison of dodecylamine-gel with kaolin and $\mathrm{MnCl}_{2} /$ heparin treatments in removing the non-specific inhibitor of haemagglutination for rubella virus serum lipoproteins, a fraction of the antibodies specific for rubella. To test this idea, a serum sample from a confirmed case of rubella infection was divided into three aliquots, treated as described in table III, and assayed for inhibitory activity and immunoglobulin concentrations. The reduction of inhibitory activity after treatment was again greatest for kaolin (table III). As for immunoglobulin levels, the largest decrease was observed in kaolin treatment and the smallest in dodecylamine-gel treatment. If it can be assumed that the removal of immunoglobulins reflects the removal of specific antibodies against rubella virus, then our results would indicate that kaolin has the least specificity in removing non-antibody-like inhibitors from serum before the titration of haemagglutination inhibitory activity.

\section{Discussion}

Compared with the other two methods, our treatment appeared to be more specific since it removed the lipoproteins completely from the sample while affecting the immunoglobulin level only slightly. On the other hand, kaolin is the least specific because it removes a significant portion of the immunoglobulins in addition to the lipoproteins. There is no direct evidence to indicate that a reduction of immunoglobulin level is necessarily associated with a reduction of rubella specific antibody level. Nevertheless, the lower inhibitory titre together with the reduction in immunoglobulin levels obtained after treatment with kaolin provide at least partial support for the claim that this procedure might have removed part of the rubella specific antibodies. By similar reasoning, both $\mathrm{MnCl}_{2} /$ heparin and dodecylaminegel treatment could have removed, perhaps to a smaller extent, a portion of the rubella specific antibodies also. Unfortunately, our present result could not provide an unequivocal answer.

The adsorption of human serum lipoproteins onto

\begin{tabular}{|c|c|c|c|c|c|c|c|c|}
\hline \multirow[t]{3}{*}{ Serum } & \multirow[t]{3}{*}{ Serum treatment } & \multicolumn{6}{|c|}{ Immunoglobulin level } & \multirow{3}{*}{$\begin{array}{l}\text { Inhibitory } \\
\text { activity }\end{array}$} \\
\hline & & \multicolumn{2}{|l|}{$I g G$} & \multicolumn{2}{|l|}{$I g M$} & \multicolumn{2}{|l|}{$\operatorname{Ig} A$} & \\
\hline & & $\begin{array}{l}\text { Conc. } \\
(\mathrm{mg} / 100 \mathrm{ml})\end{array}$ & $\begin{array}{l}\% \\
\text { change }\end{array}$ & $\begin{array}{l}\text { Conc. } \\
(\mathrm{mg} / 100 \mathrm{ml})\end{array}$ & $\begin{array}{l}\% \\
\text { change }\end{array}$ & $\begin{array}{l}\text { Conc. } \\
(\mathrm{mg} / 100 \mathrm{ml})\end{array}$ & $\begin{array}{l}\% \\
\text { change }\end{array}$ & \\
\hline 4 & $\begin{array}{c}\text { Kaolin control } \\
,, \quad \text { treated }\end{array}$ & $\begin{array}{r}1280 \\
870\end{array}$ & 30 & $\begin{array}{l}300 \\
140\end{array}$ & 53 & $\begin{array}{l}370 \\
300\end{array}$ & 22 & $\begin{array}{r}1536 \\
192\end{array}$ \\
\hline 4 & $\mathrm{MnCl}_{2} /$ heparin control & $\begin{array}{l}1440 \\
1240\end{array}$ & 14 & 272 & 11 & $\begin{array}{l}370 \\
370\end{array}$ & $\mathbf{0}$ & $\begin{array}{r}1280 \\
480\end{array}$ \\
\hline 4 & $\begin{array}{cc}\text { Dodecylamine-gel control } \\
\text { treated }\end{array}$ & $\begin{array}{l}1420 \\
1420\end{array}$ & 0 & $\begin{array}{l}312 \\
312\end{array}$ & $\mathbf{0}$ & $\begin{array}{l}384 \\
384\end{array}$ & $\mathbf{0}$ & $\begin{array}{r}1536 \\
384\end{array}$ \\
\hline 2 & $\begin{array}{cc}\text { Dodecylamine-gel control } \\
, " & \text { treated }\end{array}$ & $\begin{array}{l}940 \\
940\end{array}$ & 0 & $\begin{array}{l}256 \\
240\end{array}$ & 6 & $\begin{array}{l}216 \\
216\end{array}$ & 0 & $\begin{array}{r}256 \\
96\end{array}$ \\
\hline
\end{tabular}

Table III Comparison of kaolin. $\mathrm{MnCl}_{2} /$ heparin, and dodecylamine-gel treatments in removing serum immunoglobulins 
dodecylamine-gel is probably mediated through a hydrophobic interaction between the dodecyl chain on the gel particle and the apolar lipid moiety of the serum lipoproteins. In this connection, the reduction in the total protein content of samples treated by this method may be explained by the nonspecific adsorption of some of the serum proteins. However, for the present purpose, this non-specific absorption does not seem to affect the potential application of this method in diagnostic virology since the serum immunoglobulin levels were affected only slightly.

Although the use of dodecylamine-gel for the absorption of non-antibody-like inhibitors offers increased specificity compared with that of kaolin and $\mathrm{MnCl}_{2}$ /heparin, the adaptability of this procedure for routine use has not been evaluated. One of the problems envisaged is the difficulty in dispensing the relatively fragile gel particles for a large number of samples. A possible solution for this may be cross-linking the dodecylamine onto a more rigid solid support such as porous glass or crosslinked agarose. Another problem that may arise as a result of routine application is controlling the adsorption characteristics of the different batches of dodecylamine-gel. To this end, good quality control during the preparation of the gel as well as careful calibration of adsorption efficiencies may be the answer.

We thank Mr W. Y. Chan and Miss L. Y. Hu for skilful technical assistance and Mr D. Robinson for taking blood samples. Financial support from the World Health Foundation (Hong Kong), University of Hong Kong and a personal grant from $\mathrm{Mr}$ F. S. Ko to the Department of Biochemistry, The Chinese University of Hong Kong is gratefully acknowledged.

\section{References}

Chang, T. and Weinstein, L. (1972). Studies of nonspecific inhibition of the hemagglutinin of rubella virus and isolation and identification of the inhibitor. Amer. J. med. Sci., 263, 233-239.

Cuatrecasas, P. and Anfinsen, C. B. (1971). Affinity chromatography. In Meth. Enzymol., 22, 345-378.

Deutsch, D. G., Fogleman, D. J., and von Kaulla, K. N. (1973). Isolation of lipids from plasma by affinity chromatography. Biochem. Biophys. Res. Comm., 50, 758-764.

Feldman, H. A. (1968). Removal by heparin- $\mathrm{MnCl}_{2}$ of nonspecific rubella hemagglutinin inhibitor. Proc. Soc. exp. Biol. (N.Y.), 127, 570-573.

Hatch, F. T. and Lees, R. S. (1968). Practical methods for $\vec{\omega}$ plasma lipoprotein analysis. Advanc. Lipid Res., 6, 1-68.

Haukenes, G. and Aasen, J. (1971). Rubella haemagglutina- $\frac{9}{0}$ tion inhibitors: their separation from antibodies. Acta i path. microbiol. scand., 79B, 679-685.

Laufs, R. and Thomssen, R. (1968). Inhibition der Rubella- $\overrightarrow{-}$ virus-Hämmagglutination I. Eigenschaften eines in fetalem Kälberserum vorkommenden Inhibitors der Rubellavirus-Hämagglutination in vitro. Arch. ges. Virusforsch, 24, 181-191.

Mancini, G., Carbonara, A. O., and Heremans, J. F. (1965). Immunochemical quantitation of antigens by single radial $Z$ immunodiffusion. Immunochemistry, 2, 235-254.

Mann, J. J., Rossen, R. D., Lehrich, J. R., and Kasel, J. A. Ф (1967). The effect of kaolin on immunoglobulins: an $\vec{\gamma}$ improved technique to remove the nonspecific serum $\mathbb{\Phi}$ inhibitor of reovirus haemagglutination. J. Immunol., 98, 1136-1142.

Monath, T. P. C., Lindsey, H. S., Nuckolls, J. G., Chappe̊, W. A., and Henderson, B. E. (1970). Comparison methods for removal of nonspecific inhibitors of arbovix hemagglutination. Appl. Microbiol., 20, 748-753.

Schmidt, N. J., Gee, P. S., Dennis, J., and Lennette, E. $\overrightarrow{\mathrm{H}} . \grave{\bar{O}}$ (1971). Enzymes produced by a pseudomonas species which inactivate inhibitors of certain viral hemagglutinins. II. 응

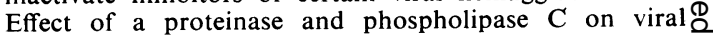
hemagglutinin inhibitors present in human sera. $J . \vec{F}$ Immunol., 106, 1615-1623.

Shortridge, K. F. and Ho, W. K. K. (1974). Human serum lipoproteins as inhibitors of haemagglutination for selected togaviruses. J. gen. Virol., 23, 113-116. 